\title{
TUNNEL DRYER AND PNEUMATIC DRYER PERFORMANCE EVALUATION TO IMPROVE SMALL-SCALE CASSAVA PROCESSING IN TANZANIA
}

\section{Running head: Tunnel dryer and pneumatic dryer performance evaluation}

\author{
MARCELO PRECOPPE ${ }^{1,4}$, ARNAUD CHAPUIS ${ }^{2}$, JOACHIM MÜLLER ${ }^{3}$, ADEBAYO ABASS $^{1}$ \\ ${ }^{1}$ International Institute of Tropical Agriculture (IITA), Dar es Salaam, Tanzania \\ ${ }^{2}$ CIRAD, UMR Qualisud, Bangkok, Thailand \\ ${ }^{3}$ Institute of Agricultural Engineering, Universität Hohenheim, Stuttgart, Germany
}

\begin{abstract}
In sub-Saharan Africa, cassava is grown by smallholder farmers and is the principal source of calories for the local population. However, the short shelf life of cassava associated with poor infrastructure in the region results in significant postharvest losses. The expansion of small-scale cassava processing could reduce these losses, but the availability of drying equipment suitable for use in such operations is limited. The objective of this research was to contribute to the development of cassava dryers suitable for use by smallholder farmers. A tunnel dryer and a pneumatic dryer being operated in Tanzania were evaluated using mass and energy balance analysis. It was found that the energy efficiency of the tunnel dryer was $29 \%$ and of the pneumatic dryer $46 \%$. For the tunnel dryer, most of the heat losses were through unsaturated exhaust air, while for the pneumatic dryer, most losses were through radiation and convection.
\end{abstract}

\section{PRACTICAL APPLICATION}

In this study, a tunnel dryer and a pneumatic dryer suitable for use by smallholder farmers were evaluated during processing centres' usual cassava drying operations. The sources and extent of heat losses were identified, and then guidelines developed on how to reduce such losses. For both dryer types, improvements to the thermal insulation used could reduce heat losses to the ambient. For the tunnel dryer, decreasing the air mass flow rate by $57 \%$ would help to minimize exhaust heat losses without producing condensation inside the unit. For the pneumatic dryer, air mass flow rate could be reduced by $9 \%$, improving energy performance without having a negative impact on the pneumatic conveying of the product. Those two modifications would be easy to implement and represent a significant contribution to the development of small-scale cassava drying technology.

\footnotetext{
${ }^{4}$ Corresponding author: Tel.: +255 22270 092; Fax: +255 22277 5021; E-mail: m.precoppe@cgiar.org
} 


\section{KEYWORDS}

Convective dryer; energy efficiency; flash dryer; specific energy consumption; mass and energy balance; heat losses.

\section{NOTATION}

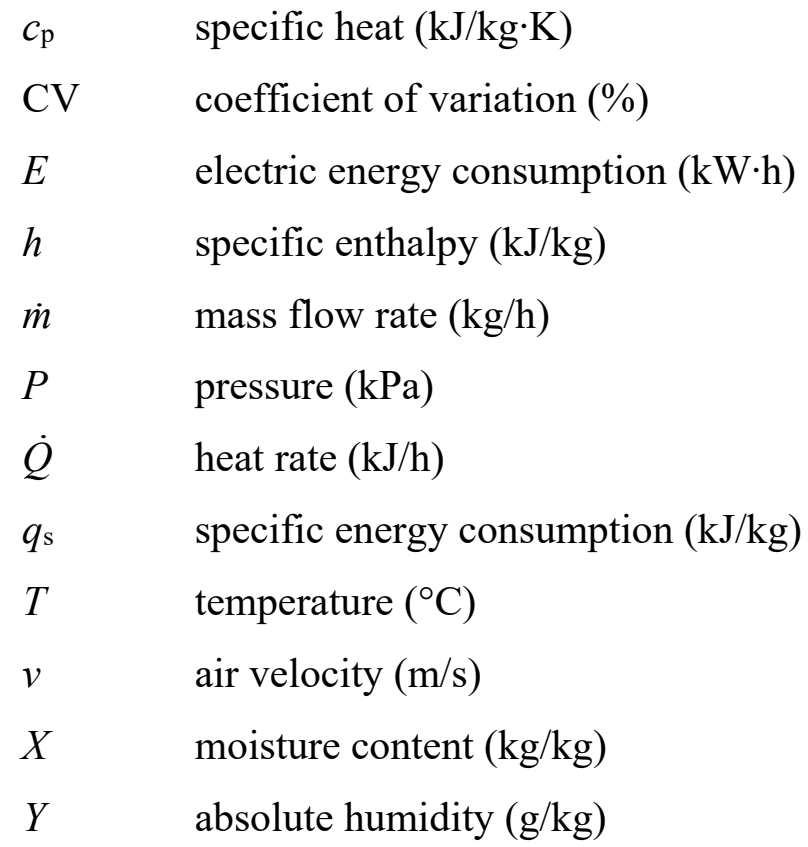

\section{Greek letters}

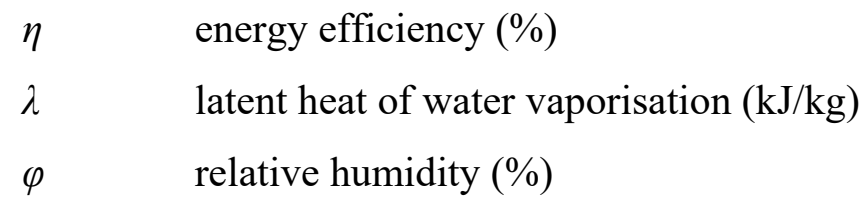

\section{Subscripts}

$\begin{array}{ll}\text { amb } & \text { ambient } \\ \mathrm{dm} & \text { dry matter } \\ \mathrm{dp} & \text { dried product } \\ \text { in } & \text { hot air entering the dryer } \\ \text { L } & \text { losses } \\ \text { out } & \text { exhaust air } \\ \text { w } & \text { water evaporation } \\ \text { wp } & \text { wet product }\end{array}$




\section{INTRODUCTION}

Cassava (Manihot esculenta Crantz) is a shrubby perennial crop from the Euphorbiaceae family that produces edible storage roots (Breuninger et al., 2009). The exact origins of cassava are still a matter for debate (Lebot, 2009), but it is generally accepted that the plant comes from the Amazon region (Beeching, 2013). The roots are rich in starch and for this reason the plant is cultivated in almost all tropical countries (Lebot, 2009). For humans, cassava is one of the major sources of carbohydrate, while for industry, cassava also plays an important role, as its starch granules have some unique features (Niba, 2005). In terms of production, cassava is the seventh most important crop in the world (Beeching, 2013) with half grown in Africa (Lebot, 2009).

Portuguese traders introduced cassava to the African continent in the $16^{\text {th }}$ Century (Spencer, 2005). At first, it was cultivated solely to supply cassava flour to the sailing ships traveling between Africa and Brazil (Lebot, 2009), but later the plant was also adopted by the local population, for use as a reserve crop in times of drought, hunger, and during locust attacks (Nweke, 2005). Nowadays, cassava is the principal source of calories for the sub-Saharan population (Wheatley et al., 2003), and it is currently produced in more than 40 African countries, mainly for human consumption (Nweke, 2005). In Africa, cassava is mostly grown by resource-poor smallholder farmers and; thus, is fundamental to both sustaining their food security and for generating an income (Beeching, 2013). The roots are used for subsistence, but are also sold at village markets and in urban centres (Nweke, 2005). However, the root's short shelf life, associated with poor transportation infrastructure and inadequate storage facilities, constrains its commercialization, and results in substantial postharvest losses across the continent (Kapinga et al., 2005).

Cassava is highly perishable (Nweke, 2005) and for this reason, the roots have long been processed to extend their shelf life. Processing methods vary widely according to the region (Spencer, 2005), but in several African countries cassava roots are dried, milled into flour and later used as the basis for a number of dishes (Wheatley et al., 2003). Processing 
cassava into flour adds value to the product, extends its shelf life and facilitates transportation (Kapinga et al., 2005). Traditionally, the roots are dried in the sun, but to obtain a higher quality, hygienic product, a dryer is required (Wheatley et al., 2003). However, the limited availability of a dryer suitable for use by smallholder farmers has hindered adoption of this postharvest technology (Orsat et al., 2008), and as a consequence has constrained the expansion of the small-scale cassava industry in Africa (Nweke, 2005).

The capital and maintenance costs incurred by both tunnel and pneumatic dryers are low, allowing them to be used within small-scale drying operations (Mujumdar, 2008, Levy and Borde, 2014). Tunnel dryers are convective dryers in which the products are placed on trays stacked on trolleys, and these trolleys then move along the drying chamber. Tunnel dryers can be used with any product which can be placed on the trays (Grabowski et al., 2005). Pneumatic dryers or flash dryers are also convective dryers, but unlike the tunnel dryer, the product being dried is entrained in the air stream, meaning that the drying medium is also used to convey the product (Brennan, 2011). Pneumatic dryers are suitable for drying products in powder or particulate form, and due to the product's short period of exposure to the drying air, they allow one to process heat-sensitive products (Rotstein and Crapiste, 1997), such as cassava (Goto, 1969).

However, dryer designs need to be tailored to the product being processed, as each has unique properties (Levy and Borde, 2014). In particular, dryer design depends on the initial and final moisture content of the product, its temperature sensitivity, and on the particle size of the material being dried (Levy and Borde, 2014, Jayaraman and Gupta, 2014). Dryer designs also need to be tailored to the users' characteristics (Chua and Chou, 2003). For smallholder farmers, a dryer should be affordable, should be low on maintenance costs (Goletti and Samman, 2007), be of a suitable processing capacity (Raoult-Wack and Bricas, 2002) and also simple to operate (Chua and Chou, 2003). State-of-the-art cassava dryers are available and are used in the food industry (Sriroth et al., 2000), but these are not suitable for use by smallholder farmers (Orsat et al., 2008). Dryers which are suitable 
for use by smallholder farmers are still at the early stages of development, their energy efficiencies are low and the resulting product is of a poor quality (Da et al., 2013).

Several studies have shown that mass and energy balance analysis can yield important information on how to improve dryer performance (Kemp and Gardiner, 2001, Strumiłło et al., 2014, Mittal, 2010, Precoppe et al., 2013), but none have dealt specifically with cassava drying. The mass and energy balance analysis of any drying process should account for the water sorption properties and the specific heat of the product being dried (Pakowski and Mujumdar, 2014), but only a limited number of studies focused on cassava drying have ever been published (Spencer, 2005). In addition, no model on cassava drying has been developed to guide dryer design in terms of dimensions, air flow rates, air temperatures and material feeding rates. The aim of this study was to (i) evaluate - using mass and energy balance analysis - two types of dryer operated by smallholder farmers in Tanzania, (ii) present information on the energy performance of the dryers and (iii) describe the modifications required to reduce heat losses.

\section{MATERIALS AND METHODS}

\section{Drying equipment}

The tunnel dryer evaluated was composed of a heating unit and an oblong drying chamber equipped with trays and trolleys, as illustrated in Fig. 1a. The drying chamber consisted of a $5.0 \mathrm{~m}$ long tunnel, $1.8 \mathrm{~m}$ high and $0.9 \mathrm{~m}$ wide, and was constructed using $20 \mathrm{~mm}$-thick plywood boards covered in aluminium sheeting. The material to be dried was loaded on to $0.60 \mathrm{~m}$ wide square trays, which were stacked one above the other $0.12 \mathrm{~m}$ apart; with 11 trays per trolley on a total of six trolleys. The heat for the drying air was supplied by a heating unit consisting of a firing system and a shell-and-tube heat exchanger, with one shell and four tube passes, and with a total exchange area of $4.36 \mathrm{~m}^{2}$. Wood shavings from a local sawmill were used as fuel. At the top of the heating unit a radial blower, powered by a $1.1 \mathrm{~kW}$ electric motor, induced air through the system. The hot air passed across the trays loaded with the wet product, and after that was exhausted via outlets at the rear of the 
unit. The trolleys were moved manually, counter-current to the air flow in a semicontinuous mode. When the operator judged the product to be sufficiently dry, the trolley at the hotter end of the tunnel was removed and another trolley, loaded with wet material, was introduced at the colder end.

The pneumatic dryer evaluated was composed of a heating unit, a drying duct and a separator, as illustrated in Fig. 1b. The heating unit was comprised of an oil burner, and a $3.70 \mathrm{~m}$ long counter-current double-pipe heat exchanger with a total exchange area of $5.94 \mathrm{~m}^{2}$. The burner was fuelled with a $1 / 3(\mathrm{v} / \mathrm{v})$ kerosene and $2 / 3(\mathrm{v} / \mathrm{v})$ waste engine oil mix. The drying duct consisted of a $1.1 \mathrm{~mm}$-thick stainless steel vertical pipe, of $0.36 \mathrm{~m}$ in diameter. The up-section of the drying duct was $8.70 \mathrm{~m}$ long, and the down-section $3.30 \mathrm{~m}$. The bend between each section had a radius of $1.00 \mathrm{~m}$. The drying duct was thermally insulated using a $50 \mathrm{~mm}$-thick mineral wool shielded with aluminium sheeting. The product to be dried was introduced to the dryer using a manual feeder set at the base of the drying duct. Once introduced, the wet material dispersed into the hot airstream and was conveyed; drying during the transport. At the end of the drying duct a cyclone separated the product from the exhaust air, where a radial blower powered by a $7.5 \mathrm{~kW}$ electric motor induced the airflow.

The dryers were located at two different processing centres in Tanzania, the tunnel dryer in KIMACECO - located at Visiga village, $60 \mathrm{~km}$ west of Dar es Salaam, and the pneumatic dryer at Ukaya Farm - located near Mkuranga village, $50 \mathrm{~km}$ south of Dar es Salaam.

\section{Drying procedure}

The facilities' usual drying procedures were followed, with the preparation process at both locations being the same. Locally grown cassava of the Kiroba variety was harvested by hand and transported the next day to the processing facility. There, it was manually peeled to remove the periderm and the cortex. After that, the roots were washed and placed on a rotary grinder. The grinder's drum was driven by a $7.5 \mathrm{~kW}$ electric motor. The material 
was then mechanically dewatered using a press, which employed a 30 tonne hydraulic jack and was able to deliver approximately 6 bar of pressure to the product. The resulting pressed cassava was introduced again into the rotary grinder to break-down the material before being added to the dryer.

For the tunnel dryer, each tray was loaded with $1 \mathrm{~kg}$ of wet material. The six trolleys were placed in the drying chamber without pre-heating. Once operating, one trolley with dried material was then removed from the hotter end of the dryer, while another trolley loaded with wet material was added from the colder end. The typical interval between the replacement of each trolley was $50 \mathrm{~min}$.

The pneumatic dryer was pre-heated for $30 \mathrm{~min}$, after which the material to be dried was manually introduced into the feeder. For both dryers, the air inlet temperature was controlled by adjusting the amount of fuel in the heating unit. For the tunnel dryer, the target temperature was $100{ }^{\circ} \mathrm{C}$ while for the pneumatic dryer it was $220{ }^{\circ} \mathrm{C}$.

\section{Measurements}

As suggested by Baker (2005), data collection was executed only after a steady-state condition had been reached. For each dryer type a total of five replications were performed; one per day over five consecutive days.

Measurements followed the guidelines set by Baker (2005) for dryer evaluation, while the sensors' specifications and placements followed the International Standard 11520-1 (ISO, 1997). Fig. 1 shows the measurements performed within both dryers. All the sensors were attached to a data acquisition system, connected to a computer, with the data recorded at 10 second intervals.

Fuel consumption was recorded gravimetrically using a digital industrial weight scale (LP7161; Avery Weigh-Tronix, Windsor, UK) attached to a data acquisition system (OMB-DAQ-54; Omega Engineering Inc., Stamford, CT). For the tunnel dryer, a bag 
containing the wood shavings was placed on the balance, after which the operator gradually removed the shavings in order to supply the heating unit. For the pneumatic dryer, the entire fuel tank was placed on the balance. Electricity consumption for both dryers was measured using a digital kilowatt-hour metre (DTS223; Volex, Maldon, UK).

The temperature of the hot air inlet, $T_{\text {in }}\left({ }^{\circ} \mathrm{C}\right)$, was measured for the tunnel dryer by placing a type $\mathrm{K}$ thermocouple at the inlet of the drying chamber, and for the pneumatic dryer by placing the thermocouple at the base of the drying duct. The pressure of the hot air inlet, $P_{\text {in }}(\mathrm{kPa})$, was measured using a temperature resistant pressure transducer (PAA35X-V-3; Omega Engineering Inc., Stamford, CT). Both sensors were attached to the OMB-DAQ54.

The temperature and relative humidity of the exhaust air ( $T_{\text {out }}$ and $\left.\varphi_{\text {out }}\right)$, and ambient air ( $T_{\mathrm{amb}}$ and $\left.\varphi_{\mathrm{amb}}\right)$, were measured using humidity-temperature probes (HC2-S; Rotronic, Bassersdorf, Switzerland). Ambient pressure, $P_{\mathrm{amb}}(\mathrm{kPa})$, was measured using a pressure transducer (PAB41X-C-800-1200; Omega Engineering Inc., Stamford, CT), with the probes attached to another data acquisition system (HygroLab 2; Rotronic, Bassersdorf, Switzerland).

For the tunnel dryer, air velocity was measured prior to the heating unit at the blower's inlet, while for the pneumatic dryer velocity was measured at the exhaust air outlet. For both dryers, a $1.5 \mathrm{~m}$ long tube was installed at the inlet/outlet to assist with the measurements. Air velocity was recorded simultaneously at different radial positions in the cross-sectional area using eight miniature hot-wire anemometers (TVS-1008; Omega Engineering Inc., Stamford, CT).

The feed rate of the wet product, $\dot{m}_{\mathrm{wp}}\left(\mathrm{kg}_{\mathrm{wet}}\right.$ product $\left./ \mathrm{h}\right)$, and the output rate of the dried product, $\dot{m}_{\mathrm{dp}}\left(\mathrm{kg}_{\text {dried product }} \mathrm{h}\right)$, were measured using a digital industrial balance. The temperature of the wet product, $T_{\mathrm{wp}}\left({ }^{\circ} \mathrm{C}\right)$, and temperature of the dried product, $T_{\mathrm{dp}}\left({ }^{\circ} \mathrm{C}\right)$, were measured by keeping one HC2-S probe inserted into the pile of material being loaded 
into the dryer, and another $\mathrm{HC} 2-\mathrm{S}$ probe inserted into the pile of material being removed from the dryer.

\section{Sample collection and laboratory analysis}

During the evaluation, one set of wet and dried product samples was collected per day, but only after the systems had reached a steady-state condition. For the tunnel dryer, wet samples were taken before placing the trolley inside the chamber, and dried samples were collected after removing the trolley from the dryer. Samples were collected from trays located in the top, middle and bottom of the trolley. For the pneumatic dryer, wet samples were collected from the feeder and dried samples collected at the cyclone outlet.

The moisture content of the wet and dried samples was determined using the gravimetric method with three replications (ASABE, 2008). The material was dried for $24 \mathrm{~h}$ at $103{ }^{\circ} \mathrm{C}$ using a convection oven (DL-53; VWR, Radnor, PA). Carbohydrate content was determined according to DuBois et al. (1956) using a spectrophotometer (Genova; Jenway, Staffordshire, UK), while ash content was determined according to method 923.03 (AOAC, 1998a) and using a furnace (LT 40/12; Nabertherm, Walsrode, Germany). Furthermore, fibre content was determined according to method 985.29 (AOAC, 1998d) and using a fibre analyser (Fibertec 1020; Foss, Hillerød, Denmark), fat content was determined according to method 983.23 (AOAC, 1998b) and using an extraction unit (Soxtec 2043; Foss, Hillerød, Denmark), and protein content was determined according to method 920.87 (AOAC, 1998c) and using a digestion system (DT 20; Foss, Hillerød, Denmark).

The incipient fluidization velocity, i.e. the minimum air velocity required to suspend the particles, and the entrainment velocity, i.e. the minimum air velocity required to transport the particles, were determined experimentally using an analytical pneumatic conveyor. This equipment, developed by Universität Hohenheim (Stuttgart, Germany), featured a feeding hopper, a transparent vertical conveying tube, a cyclone and a radial blower with 
adjustable speed settings. The incipient fluidization velocity and the entrainment velocity were determined as described by Karaj and Müller (2010), varying the speed of the blower and observing at the transparent duct the minimum air velocity needed to suspend the product and the minimum air velocity needed to transport it.

Samples of the fuels used in the dryers were collected and their higher heating values determined according to DIN 51900-3 (2005), and using an oxygen bomb calorimeter (6100 Calorimeter; Parr Instrument Company, Moline, IL).

\section{Mass and energy balance analysis}

Specific energy consumption, $q_{\mathrm{s}}\left(\mathrm{kJ} / \mathrm{kg}_{\text {water }}\right)$, was defined as the ratio between the heat rate added to the ambient air, $\dot{Q}_{\Delta}(\mathrm{kJ} / \mathrm{h})$, and the water evaporation rate, $\dot{m}_{\mathrm{w}}\left(\mathrm{kg}_{\mathrm{water}} / \mathrm{h}\right)$, as shown in Equation 1 (Kudra, 2009):

$$
q_{\mathrm{s}}=\frac{\dot{Q}_{\Delta}}{\dot{m}_{\mathrm{w}}}=\frac{\dot{m}_{\mathrm{air}}\left(h_{\mathrm{in}}-h_{\mathrm{amb}}\right)}{\dot{m}_{\mathrm{dm}}\left(X_{\mathrm{wp}}-X_{\mathrm{dp}}\right)}
$$

Where: $\dot{m}_{\text {air }}\left(\mathrm{kg}_{\text {dry air }} / \mathrm{h}\right)$ is the specific air mass flow rate, $h_{\text {in }}\left(\mathrm{kJ} / \mathrm{kg}_{\text {dry air }}\right)$ is the specific enthalpy of the hot air inlet, $h_{\mathrm{amb}}\left(\mathrm{kJ} / \mathrm{kg}_{\text {dry air }}\right)$ is the specific enthalpy of the ambient air, and $\dot{m}_{\mathrm{dm}}\left(\mathrm{kg}_{\mathrm{dm}} / \mathrm{h}\right)$ is the dry-basis feed rate. $X_{\mathrm{wp}}$ and $X \mathrm{dp}\left(\mathrm{kg}_{\mathrm{water}} / \mathrm{kg}_{\mathrm{dm}}\right)$ are the moisture content of the wet product and of the dried product respectively. The value for $h$ amb was calculated from $T_{\mathrm{amb}}, P_{\mathrm{amb}}$ and the absolute humidity of the ambient air, $Y_{\mathrm{amb}}\left(\mathrm{kg}_{\mathrm{water}} / \mathrm{kg}_{\mathrm{dry}}\right.$ air$)$. Likewise, $h_{\text {in }}$ was calculated from $T_{\text {in }}, P_{\text {in }}$ and the absolute humidity of the hot air inlet

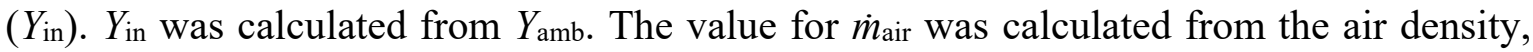
air velocity and cross sectional area, while air density was determined based on the air temperature, relative humidity and pressure, using the CIPM-2007 formula (Picard et al., 2008). The psychrometric calculations used equations presented by WMO (2008).

Energy efficiency, $\eta_{\mathrm{e}}(\%)$, was defined according to Kudra (2009) as the ratio between the heat rate used for water evaporation, $\dot{Q}_{\mathrm{w}}(\mathrm{kJ} / \mathrm{h})$, and $\dot{Q}_{\Delta}$, as shown in Equation 2: 


$$
\eta_{\mathrm{e}}=\frac{\dot{Q}_{\mathrm{w}}}{\dot{Q}_{\Delta}}=\frac{\dot{m}_{\mathrm{w}} \cdot \lambda}{\dot{Q}_{\Delta}}
$$

Where: $\lambda\left(\mathrm{kJ} / \mathrm{kg}_{\text {water }}\right)$ is the latent heat of water vaporisation, calculated by entering $T_{\mathrm{wp}}$ into the Watson equation (Watson, 1943). Desorption enthalpy was not considered, as suggested by Gevaudan et al. (1989).

Thermal efficiency, $\eta$ т, was defined according to Strumiłło et al. (2014) based on the inlet air temperature $\left(T_{\mathrm{in}}\right)$, the outlet air temperature $\left(T_{\mathrm{out}}\right)$ and the ambient temperature $\left(T_{\mathrm{amb}}\right)$, as shown in Equation 3:

$$
\eta_{\mathrm{T}}=\frac{T_{\text {in }}-T_{\text {out }}}{T_{\text {in }}-T_{\text {amb }}}
$$

Heat losses to the ambient, $\dot{Q}_{\mathrm{L}, \mathrm{amb}}(\mathrm{kJ} / \mathrm{h})$, encompassing radiation and convection heat losses, were determined from the dryer's energy balance, as suggested by Rotstein and Crapiste (1997). This calculation took into consideration the heat input rate $\dot{Q}_{\text {in }}(\mathrm{kJ} / \mathrm{h})$, the energy input rate of the wet product, $\dot{Q}_{\mathrm{wp}}(\mathrm{kJ} / \mathrm{h})$, the heat output rate from the exhaust air, $\dot{Q}_{\text {out }}(\mathrm{kJ} / \mathrm{h})$, and the energy output of the dried product, $\dot{Q}_{\mathrm{dp}}(\mathrm{kJ} / \mathrm{h})$, as shown in Equation 4 :

$$
\dot{Q}_{\mathrm{L}, \mathrm{amb}}=\left(\dot{Q}_{\mathrm{in}}+\dot{Q}_{\mathrm{wp}}\right)-\left(\dot{Q}_{\mathrm{out}}+\dot{Q}_{\mathrm{dp}}\right)=\left(h_{\mathrm{in}} \cdot \dot{m}_{\mathrm{air}}+h_{\mathrm{wp}} \cdot \dot{m}_{\mathrm{dm}}\right)-\left(h_{\mathrm{out}} \cdot \dot{m}_{\mathrm{air}}+h_{\mathrm{dp}} \cdot \dot{m}_{\mathrm{dm}}\right)
$$

Where: $h_{\text {out }}\left(\mathrm{kJ} / \mathrm{kg}_{\mathrm{dry}}\right.$ air $)$ is the specific enthalpy of the exhaust air, $h_{\mathrm{wp}}\left(\mathrm{kJ} / \mathrm{kg}_{\mathrm{dm}}\right)$ is the specific enthalpy of the wet product, and $h_{\mathrm{dp}}\left(\mathrm{kJ} / \mathrm{kg}_{\mathrm{dm}}\right)$ is the specific enthalpy of the dried product. The value for $h_{\mathrm{out}}$ was calculated from $T_{\mathrm{out}}$ and $\varphi_{\mathrm{out}}$. The values for $h_{\mathrm{wp}}$ and $h_{\mathrm{dp}}$ were calculated from the product temperature and specific heat, $c_{\mathrm{p}}\left(\mathrm{kJ} / \mathrm{kg}_{\mathrm{dm}} \cdot \mathrm{K}\right)$. The value for $c_{\mathrm{p}}$ was determined according to Ibarz and Barbosa-Cánovas (2002), and using the correlations postulated by Choi and Okos (1986); entering the product temperature and the moisture, carbohydrate, ash, fibre, fat, and protein contents.

Heat losses via exhaust air, $\dot{Q}_{\mathrm{L}, \mathrm{out}}(\mathrm{kJ} / \mathrm{h})$, were determined according to Kudra (2009), taking into consideration the minimum air flow rate required to supply both heat and 
hydrodynamic demand. $\dot{Q}_{\mathrm{L}, \text { out }}$ was calculated by subtracting from $\dot{Q}_{\text {out }}$ the exhaust heat rate based on a minimum air flow rate, $\dot{Q}_{\text {out }}^{*}(\mathrm{~kJ} / \mathrm{h})$ :

$$
\dot{Q}_{\mathrm{L}, \text { out }}=\dot{Q}_{\text {out }}-\dot{Q}_{\text {out }}^{*}=\left(h_{\text {out }} \cdot \dot{m}_{\text {air }}\right)-\left(h_{\text {out }} \cdot \dot{m}_{\text {air }}^{*}\right)=h_{\text {out }}\left(\dot{m}_{\text {air }}-\dot{m}_{\text {air }}^{*}\right)
$$

Where: $\dot{m}_{\text {air }}^{*}$ is the minimum air mass flow rate; calculated dividing $\dot{m}_{\mathrm{w}}$ by the equilibrium absolute humidity of exhaust air $Y_{\text {out }}^{*}\left(\mathrm{~kg}_{\text {water }} / \mathrm{kg}_{\mathrm{dry}}\right.$ air $)$, and taking into consideration the absolute humidity of the ambient air, $Y_{\mathrm{amb}}\left(\mathrm{kg}_{\mathrm{water}} / \mathrm{kg}_{\mathrm{dry}}\right.$ air $)$ :

$$
\dot{m}_{\mathrm{air}}^{*}=\frac{\dot{m}_{\mathrm{w}}}{Y_{\mathrm{out}}^{*}-Y_{\mathrm{amb}}}
$$

$Y_{\text {out }}^{*}$ was calculated from the sorption isotherms using the modified Halsey model (Iglesias and Chirife, 1976) and the parameters for cassava desorption presented by Aviara and Ajibola (2002). To find $Y_{\text {out }}^{*}$, first $\varphi_{\text {out }}^{*}$ and $T_{\text {out }}^{*}$ had to be calculated. The values for $\varphi_{\text {out }}^{*}$ and $T_{\text {out }}^{*}$ were determined taking into account the enthalpy of the exhaust air and the desorption equation. The calculation was solved based on an enthalpy equal to $h_{\text {out }}$ and an equilibrium product moisture content of $14.0 \% \mathrm{wb}$, while retaining the highest possible air relative humidity.

\section{RESULTS}

\section{Tunnel dryer}

Over the course of the trial, the average ambient temperature for the tunnel dryer was $33.7 \pm 1.7^{\circ} \mathrm{C}$ and the average ambient relative humidity was $52.4 \pm 8.0 \%$. After a steady condition had been achieved, the dryer was fed with $13.2 \pm 0.0 \mathrm{~kg}$ of wet product per hour. The average moisture content of the wet product was $47.7 \pm 2.7 \%$ wp. Trolleys were moved forward every $50 \mathrm{~min}$, with a trolley holding wet product added at one end, and a trolley holding dried product removed from the other. The dried product output rate was $8.0 \pm 0.1 \mathrm{~kg} / \mathrm{h}$, and the average moisture content of the dried product was $14.0 \pm 5.9 \%$ wb. The dryer's heating unit was fuelled with $9.0 \pm 0.8 \mathrm{~kg} / \mathrm{h}$ of wood shavings, which had a 
calorific value of $22.40 \pm 3.28 \mathrm{MJ} / \mathrm{kg}$. The average temperature of the hot air at the inlet was $125.5 \pm 12.9^{\circ} \mathrm{C}$, and the electrical power input was $0.41 \pm 0.01 \mathrm{~kW}$. Table 1 shows the performance indices obtained for the tunnel dryer.

The average air mass flow rate was $450.6 \pm 12.9 \mathrm{~kg}_{\mathrm{dry}}$ air $/ \mathrm{h}$, and the calculated minimum air mass flow rate was $195.7 \mathrm{~kg}_{\mathrm{dry}}$ air $/ \mathrm{h}$. The temperature of the exhaust air was $73.4 \pm 7.2^{\circ} \mathrm{C}$, relative humidity was $13.8 \pm 3.5 \%$ and specific enthalpy was $156.3 \pm 11.8 \mathrm{~kJ} / \mathrm{kg}_{\text {dry }}$ air. If the minimum air mass flow rate had been used, the temperature of the exhaust air $\left(T_{\text {out }}^{*}\right)$ would have decreased to $43.4^{\circ} \mathrm{C}$, the relative humidity $\left(\varphi_{\text {out }}^{*}\right)$ would have increased to $75.0 \%$ and the specific enthalpy would have remained the same. At those conditions, the product equilibrium moisture content, predicted by the sorption isotherm, would have been $13.6 \pm 0.4 \%$ wb.

\section{Pneumatic dryer}

Over the course of the trial, the average ambient temperature for the pneumatic dryer was $30.0 \pm 1.1^{\circ} \mathrm{C}$ and average ambient relative humidity was $53.6 \pm 6.2 \%$. After a steady condition had been achieved, the dryer was fed with $325.9 \pm 45.7 \mathrm{~kg}$ of wet product per hour. The average moisture content of the wet product was $46.1 \pm 0.8 \%$ wp. The dried product output rate was $208.5 \pm 37.0 \mathrm{~kg} / \mathrm{h}$ and the average moisture content of the dried product was $15.3 \pm 3.7 \%$ wb. The heating unit of the dryer was fuelled with $25.3 \pm 2.5 \mathrm{~kg} / \mathrm{h}$ of the kerosene/waste-oil mixture, which had a calorific value of $43.13 \pm 4.09 \mathrm{MJ} / \mathrm{kg}$. The average temperature of the hot air at the inlet was $275.6 \pm 16.2{ }^{\circ} \mathrm{C}$. The electrical power input was $5.63 \pm 0.66 \mathrm{~kW}$. Table 2 shows the performance indices obtained for the pneumatic dryer.

The average air mass flow rate was $2320.8 \pm 6.4 \mathrm{~kg}$ dry air $/ \mathrm{h}$ and the calculated minimum air mass flow rate was $2107.0 \mathrm{~kg}_{\text {dry air }} / \mathrm{h}$. The temperature of the exhaust air was $59.5 \pm 1.4{ }^{\circ} \mathrm{C}$, relative humidity was $49.6 \pm 5.6 \%$ and specific enthalpy was $232.3 \pm 8.7 \mathrm{~kJ} / \mathrm{kg}_{\text {dry air. }}$ If the minimum air mass flow rate had been used, the temperature of the exhaust air $\left(T_{\text {out }}^{*}\right)$ would 
have decreased to $50.2{ }^{\circ} \mathrm{C}$, relative humidity $\left(\varphi_{\text {out }}^{*}\right)$ would have increased to $81.5 \%$ and specific enthalpy would have remained the same. At those conditions, the product equilibrium moisture content, as predicted by the sorption isotherm, would have been $13.8 \pm 0.2 \%$ wb.

Air velocity in the drying pipe was $10.2 \pm 0.3 \mathrm{~m} / \mathrm{s}$. If the minimum air mass flow had been used, the air velocity would have decrease to $9.3 \mathrm{~m} / \mathrm{s}$. This would not have jeopardized the pneumatic conveying of the product because the measured minimum entrainment velocity was $6.0 \pm 0.5 \mathrm{~m} / \mathrm{s}$ and the incipient fluidization velocity was $4.1 \pm 0.4 \mathrm{~m} / \mathrm{s}$.

\section{DISCUSSION}

\section{Product moisture content}

At both the drying centres, after pressing the moisture content level was close to the values reported by Tivana et al. (2010), who used a similar pressing system. However, Gevaudan et al. (1989) reported lower moisture content levels after pressing, suggesting that the mechanical dewatering processes used could be improved.

For cassava flour, a moisture content below $14 \%$ wb is recommended for safe storage (Onayemi and Oluwamukomi, 1987, Ayensu, 1997). To reach this recommended final moisture content, processing centres have two options. First, they could reduce the initial moisture content of the ground cassava using a mechanical dewatering process. According to Strumiłło et al. (2014), substantial energy savings can be achieved when a mechanical dewatering process is used to reduce initial moisture content. Alternatively, processing centres could increase the amount of time the product spends inside the dryer. Tunnel dryer residence time can easily be controlled by changing the intervals at which the trolleys are replaced inside the chamber (Brennan, 2011). For the pneumatic dryer, residence time can be adjusted either by changing the cross-sectional area of the drying duct (Mujumdar, 2008) and so reducing air velocity, or by modifying the length of the drying duct (Brennan, 2011). Finally, for the pneumatic dryer, a third alternative would be to improve the cassava 
grinding method, so as to obtain a smaller particle size and as a consequence increase the rate at which drying takes place (Sokhansanj and Jayas, 2014). The added advantage of this option is that no modifications to the dryer are required.

In the study, neither dryer had an automated control system. As a consequence of this, the operations of both were marked by non-uniformity. The moisture content of the wet product introduced to both dryers was not homogeneous, and the operators of both dryers had difficulty keeping the inlet air temperature constant. This resulted in a dried product with a non-uniform moisture content; the coefficient of variation (CV) was $42 \%$ for the tunnel dryer and $24 \%$ for the pneumatic dryer. Such a high CV would create problems to commercialize (Bena and Fuller, 2002) and store the product (Müller and Mühlbauer, 2011).

\section{Mass and energy balance analysis}

To produce $1 \mathrm{~kg}$ of dried product using the tunnel dryer, $5.5 \pm 0.9 \mathrm{MJ}$ of heat was needed, while to produce the same amount using the pneumatic dryer, 3.1 $\pm 0.7 \mathrm{MJ}$ was required. Energy consumption is usually elevated in convective dryers due to the poor contact between the drying air and wet material (Kudra, 2012). However, in pneumatic dryers the degree of dispersion is very high because the material is entrained in the hot airstream (Levy and Borde, 2014). As a consequence, the level of contact between the drying air and wet material is better (Jayaraman and Gupta, 2014), and this explains the superior overall energy performance of the pneumatic dryer. The only drawback is that in order to produce the right hydrodynamic conditions within a pneumatic dryer, a substantial amount of electrical energy is used to power the blowers (Kudra, 2009).

Ideally, 2.5 MJ of energy is needed to evaporate $1 \mathrm{~kg}$ of water (Strumiłło et al., 2014), but the $q_{\mathrm{s}}$ values obtained here were substantially higher. The reason for this was because of the heat losses and due to the internal resistance that the material performed against the moisture movement (Salgado-Cervantes et al., 1994). For cassava drying water diffusivity is the main factor governing drying rate (Igbeka, 1982) and therefore this resistance to 
water movement is important to the dryer's mass and energy balance analysis. According to Mujumdar (2014), the specific energy consumption of a tunnel dryer ranges from 5.5 to

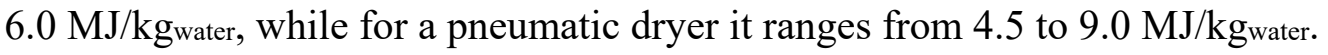

The energy efficiency of convective dryers is typically between $20 \%$ and $60 \%$ (Strumiłło et al., 2014). Aviara et al. (2014) dried cassava starch using a tray dryer, and reported energy efficiency between $16 \%$ and $31 \%$. Meanwhile, Forson et al. (2007) dried cassava chips with a solar dryer, reporting an average energy efficiency of $13 \%$.

The thermal efficiency of tunnel dryers ranges from $35 \%$ to $60 \%$, and of pneumatic dryers from $50 \%$ to $75 \%$ (Rotstein and Crapiste, 1997). The thermal efficiencies obtained for both the dryers in this study were at the high end and above these ranges, due to the elevated temperature of the hot air inlet. To maximize thermal efficiency, the temperature of the drying air should be as high as possible, but should not exceed the limits imposed by the thermal sensitivity of the product being dried. In this study, the hot air inlet temperature was substantially higher than the temperature targeted by the operator. The high $T_{\text {in }}$ resulted in a better thermal efficiency but could have serious consequences for product quality, because gelatinization occurs when the cassava's starch granules are heated above $66{ }^{\circ} \mathrm{C}$ (Stevens and Elton, 1971). In this respect, pneumatic dryers also have an important advantage over tunnel dryers, as the short contact time and fast evaporation rates seen in pneumatic dryers allow for higher temperatures to be used without overheating the product (Rotstein and Crapiste, 1997, Brennan, 2011, Levy and Borde, 2014).

Heat losses to the ambient depend on the thermal properties of the dryer walls, the dimensions of the dryer and its operating conditions (Rotstein and Crapiste, 1997). In general, losses of this kind from convective dryers range from $3 \%$ to $10 \%$ (Strumiłło et al., 2014) and are usually higher in small dryers due to the high surface-to-volume ratio (Kemp, 2012). For the studied tunnel dryer, the surface to volume ratio was $3.75 \mathrm{~m}^{2} / \mathrm{m}^{3}$, while for the pneumatic dryer it was $5.69 \mathrm{~m}^{2} / \mathrm{m}^{3}$. Precoppe et al. (2011) evaluated a smallscale cabinet dryer with a surface-to-volume ratio of $4.50 \mathrm{~m}^{2} / \mathrm{m}^{3}$, and obtained heat losses 
to the ambient higher than for the tunnel dryer, but lower than for the pneumatic dryer. These kinds of losses can be reduced by improving the thermal insulation used in the dryer walls and duct (Kudra, 2009, Gong et al., 2011).

Exhaust heat losses are frequently high in convective dryers (Kudra, 2012), and usually range between $15 \%$ and $40 \%$ (Strumiłło et al., 2014). Such losses can be reduced by recirculating a proportion of the drying air. However, this requires extensive modifications to be made to the dryer (Gong et al., 2011), and for a pneumatic dryer can increase the risk of dust explosion (Rotstein and Crapiste, 1997, Markowski and Mujumdar, 2014). Another way to reduce exhaust heat losses is by reducing the air mass flow rate (Kudra, 2009). It is possible to reduce the air mass flow rate without decreasing the drying rate, because during the cassava drying process, the main factor limiting evaporation is the speed at which the internal moisture moves within the solid, and this is controlled by internal diffusion (Igbeka, 1982). As a result, the influence of the air mass flow rate is negligible (Kudra, 2009).

In a pneumatic dryer, when reducing the air mass flow rate, it is important to verify whether the air velocity at the drying duct remains above the minimum velocity needed to fluidize and transport the material (Levy and Borde, 2014). In cases where the minimum entrainment or incipient fluidization velocities do not allow a reduction of the air mass flow rate to take place, the cassava grinding method needs to be changed. For example, the rotary grinder could be replaced by a hammer mill, resulting in a smaller particle size and so reducing both the incipient fluidization velocity and the entrainment velocity (Rotstein and Crapiste, 1997).

\section{CONCLUSIONS}

In this study, the pneumatic dryer presented higher efficiency and lower heat losses via the exhaust air than the tunnel dryer. This is because in a pneumatic dryer, the contact between the drying air and the product is better than in a tunnel dryer. The energy performance of 
both dryers could be improved by adding thermal insulation and by reducing the drying air mass flow rates used. Despite the better energy performance of the pneumatic dryer, when considering the setting in sub-Saharan Africa, the tunnel dryer may be more suitable, as it is more affordable and is simpler to operate and maintain, characteristics that are of fundamental importance to smallholder farmers.

\section{ACKNOWLEDGEMENTS}

This study was conducted as part of the CGIAR research program named "Roots, Tubers and Bananas”. Mr. Sebastian Romuli (Universität Hohenheim) should be acknowledged for his measurements using the analytical pneumatic conveyor. We should also express our gratitude to KIMACECO and Ukaya Farm processing centres for taking part in this study. We would also like to thank Dr. Thierry Tran (CIRAD) for his helpful suggestions during the writing of this paper.

\section{REFERENCES}

AOAC. 1998a. Ash of flour (method 923.03). In Official Methods of Analysis, Assoc. of Official Analytical Chemists, Gaithersburg, MD.

AOAC. 1998b. Fat in foods (method 983.23). In Official Methods of Analysis, Assoc. of Official Analytical Chemists, Gaithersburg, MD.

AOAC. 1998c. Protein (total) in flour (method 920.87). In Official Methods of Analysis, Assoc. of Official Analytical Chemists, Gaithersburg, MD.

AOAC. 1998d. Total dietary fiber in foods (method 985.29). In Official Methods of Analysis, Assoc. of Official Analytical Chemists, Gaithersburg, MD.

ASABE. 2008. ASAE S358.2 DEC1988 (R2008) Moisture measurements - Forages. In ASABE Standards 2008: Standards Engineering Practices Data, pp. 670-672, American Society of Agricultural and Biological Engineers, St. Joseph, MO.

AVIARA, N. A. and AJIBOLA, O. O. 2002. Thermodynamics of moisture sorption in melon seed and cassava. J. Food Eng., 55, 107-113.

AVIARA, N. A., ONUOHA, L. N., FALOLA, O. E. and IGBEKA, J. C. 2014. Energy and exergy analyses of native cassava starch drying in a tray dryer. Energy, 73, 809817. 
AYENSU, A. 1997. Dehydration of food crops using a solar dryer with convective heat flow. Solar Energy, 59, 121-126.

BAKER, C. G. J. 2005. Energy efficient dryer operation - An update on developments. Drying Technol., 23, 2071-2087.

BEECHING, J. R. 2013. Manihot esculenta (Cassava). In ELS, pp. 1-7, John Wiley \& Sons, Ltd, Chichester, UK.

BENA, B. and FULLER, R. J. 2002. Natural convection solar dryer with biomass back-up heater. Solar Energy, 72, 75-83.

BRENNAN, J. G. 2011. Evaporation and dehydration. In Food Processing Handbook, (J. G. Brennan \& A. S. Grandison, eds.) pp. 77-130, $2^{\text {nd }}$ Ed., WILEY-VCH Verlag GmbH, Weinheim, Germany.

BREUNINGER, W. F., PIYACHOMKWAN, K. and SRIROTH, K. 2009. Tapioca/cassava starch: Production and use. In Starch, (J. Bemiller \& R. Whistler, eds.) pp. 541568, $3^{\text {rd }}$ Ed., Academic Press, San Diego, CA.

CHOI, Y. and OKOS, M. R. 1986. Effects of temperature and composition on the thermal properties of foods. In Food Engineering and Process Applications, (M. L. Maguer \& P. Jelen, eds.) pp. 93-101, Elsevier Applied Science Publishers, London, UK.

CHUA, K. J. and CHOU, S. K. 2003. Low-cost drying methods for developing countries. Trends in Food Science and Technology, 14, 519-528.

DA, G., DUFOUR, D., GIRALDO, A., MORENO, M., TRAN, T., VELEZ, G., SANCHEZ, T., LE-THANH, M., MAROUZE, C. and MARECHAL, P.-A. 2013. Cottage Level Cassava Starch Processing Systems in Colombia and Vietnam. Food and Bioprocess Technology, 6, 2213-2222.

DIN 51900-3. 2005. Determination of gross calorific value by the bomb calorimeter and calculation of net calorific value, DIN Deutsches Institut für Normung, Berlin, Germany.

DUBOIS, M., GILlES, K. A., HAMILTON, J. K., REBERS, P. A. and SMITH, F. 1956. Colorimetric method for determination of sugars and related substances. Anal. Chem., 28, 350-356.

FORSON, F. K., NAZHA, M. A. A. and RAJAKARUNA, H. 2007. Modelling and experimental studies on a mixed-mode natural convection solar crop-dryer. Solar Energy, 81, 346-357.

GEVAUDAN, A., CHUZEL, G., DIDIER, S. and ANDRIEU, J. 1989. Physical properties of cassava mash. Int. J. Food Sci. Tech., 24, 637-645.

GOLETTI, F. and SAMMAN, E. 2007. Post-harvest systems in world agriculture. In Crop Post-Harvest: Science and Technology, pp. 1-34, Blackwell Science Ltd, Malden, MA. 
GONG, Z. X., STANOVSKÝ, J. and MUJUMDAR, A. S. 2011. Energy audit of a fiberboard drying production line using simprosys software. Drying Technol., 29, 408-418.

GOTO, F. 1969. Determination of gelatinization property of highly concentrated starch suspension by brabender olastograph. Part 2. Examination of gelatinization curve obtained by plastograph. Starch - Stärke, 21, 267-270.

GRABOWSKI, S., MARCOTTE, M. and RAMASWAMY, H. 2005. Dehydrated vegetables. In Handbook of Food Science, Technology, and Engineering, (Y. H. Hui, ed.) pp. 2021-2037, CRC Press, Boca Raton, FL.

IBARZ, A. and BARBOSA-CÁNOVAS, G. V. 2002. Unit Operations in Food Engineering, CRC Press, Boca Raton, FL.

IGBEKA, J. C. 1982. Simulation of moisture movement during drying a starchy food product - cassava. Int. J. Food Sci. Tech., 17, 27-36.

IGLESIAS, H. A. and CHIRIFE, J. 1976. Prediction of the effect of temperature on water sorption isotherms of food material. Int. J. Food Sci. Tech., 11, 109-116.

ISO. 1997. International Standard 11520-1:1997 Agricultural grain dryer - Determination of drying performance, International Organization of Standardization, Geneva, Switzerland.

JAYARAMAN, K. S. and GUPTA, D. K. D. 2014. Drying of fruits and vegetables. In Handbook of Industrial Drying, (A. S. Mujumdar, ed.) pp. 611-635, $4^{\text {th }}$ Ed., CRC Press, Boca Raton, FL.

KAPINGA, R., MAFURU, J., JEREMIAH, S., RWIZA, E., KAMALA, R., MASHAMBA, F. and MLINGI, N. 2005. Status of cassava in Tanzania. In $A$ review of cassava in Africa with country case studies on Nigeria, Ghana, the United Republic of Tanzania, Uganda and Benin, pp. 100-193, FAO, Rome.

KARAJ, S. and MÜLLER, J. 2010. Determination of physical, mechanical and chemical properties of seeds and kernels of Jatropha curcas L. Industrial Crops and Products, 32, 129-138.

KEMP, I. C. 2012. Modern drying technology: Energy savings. In Volume 4: Energy Savings, (E. Tsotsas \& A. S. Mujumdar, eds.) pp. 1-45, Wiley-VCH Verlag GmbH \& Co. KGaA, Weinheim, Germany.

KEMP, I. C. and GARDINER, S. P. 2001. An outline method for troubleshooting and problem-solving in dryers. Drying Technol., 19, 1875-1890.

KUDRA, T. 2009. Energy aspect in food dehydration. In Advances in Food Dehydration, (C. Ratti, ed.) pp. 423-445, CRC Press, Boca Raton, FL.

KUDRA, T. 2012. Energy performance of convective dryers. Drying Technol., 30, 11901198. 
LEBOT, V. 2009. Tropical Root and Tuber Crops: Cassava, Sweet Potato, Yams and Aroids, CABI, Wallingford, CT.

LEVY, A. and BORDE, I. 2014. Pneumatic and flash drying. In Handbook of Industrial Drying, (A. S. Mujumdar, ed.) pp. 381-392, 4th Ed., CRC Press, Boca Raton, FL.

MARKOWSKI, A. S. and MUJUMDAR, A. S. 2014. Safety aspects of industrial dryers. In Handbook of Industrial Drying, (A. S. Mujumdar, ed.) pp. 1127-1151, $4^{\text {th }}$ Ed., CRC Press, Boca Raton, FL.

MITTAL, G. S. 2010. Mass and energy balances in food processing. In Mathematical Modeling of Food Processing, pp. 109-122, CRC Press.

MUJUMDAR, A. S. 2008. Drying principles and practice. In Albright's Chemical Engineering Handbook, (L. F. Albright, ed.) pp. 1667-1716, CRC Press, Boca Raton, FL.

MUJUMDAR, A. S. 2014. Principles, classification, and selection of dryers. In Handbook of Industrial Drying, (A. S. Mujumdar, ed.) pp. 3-29, $4^{\text {th }}$ Ed., CRC Press, Boca Raton, FL.

MÜLLER, J. and MÜHLBAUER, W. 2011. Solar drying. In Modern Drying Technology, (E. Tsotsas \& A. S. Mujumdar, eds.) pp. 199-243, Wiley-VCH Verlag GmbH \& Co. KGaA, Weinheim, Germany.

NIBA, L. L. 2005. Carbohydrates: Starch. In Handbook of Food Science, Technology, and Engineering, (Y. H. Hui, ed.) pp. 68-84, CRC Press, Boca Raton, FL.

NWEKE, F. I. 2005. The cassava transformation in Africa. In A review of cassava in Africa with country case studies on Nigeria, Ghana, the United Republic of Tanzania, Uganda and Benin, pp. 16-61, FAO, Rome.

ONAYEMI, O. and OLUWAMUKOMI, M. O. 1987. Moisture equilibria of some dehydrated cassava and yam products. J. Food Process Eng., 9, 191-200.

ORSAT, V., VIJAYA RAGHAVAN, G. S. and SOSLE, V. 2008. Adapting drying technologies for agri-food market development in India. Drying Technol., 26, $1355-1361$.

PAKOWSKI, Z. and MUJUMDAR, A. S. 2014. Basic process calculations and simulations in drying. In Handbook of Industrial Drying, $4^{\text {th }}$ Edition, (A. S. Mujumdar, ed.) pp. 51-75, CRC Press, Boca Raton, FL.

PICARD, A., DAVIS, R. S., GLÄSER, M. and FUJII, K. 2008. Revised formula for the density of moist air (CIPM-2007). Metrologia, 45, 149-155.

PRECOPPE, M., JANJAI, S., MAHAYOTHEE, B. and MÜLLER, J. 2013. Improved energy efficiency of farmers' cooperative litchi drying operation in Northern Thailand. Int. J. Food Sci. Tech., 48, 2376-2383. 
PRECOPPE, M., NAGLE, M., JANJAI, S., MAHAYOTHEE, B. and MÜLLER, J. 2011. Analysis of dryer performance for the improvement of small-scale litchi processing. Int. J. Food Sci. Tech., 46, 561-569.

RAOULT-WACK, A. and BRICAS, N. 2002. Sustainability of food sector development in tropical areas. In Engineering and Food for the 21st Century, (J. Welti-Chanes, G. V. Barbosa-Cánovas \& J. M. Aguilera, eds.) pp. 40-55, CRC Press, Boca Raton, FL.

ROTSTEIN, E. and CRAPISTE, G. H. 1997. Design and performance evaluation of dryers. In Handbook of Food Engineering Practice, (K. J. Valentas, R. P. Singh \& E. Rotstein, eds.) pp. 121-162, CRC Press, Boca Raton, FL.

SALGADO-CERVANTES, M., GARCIA-ALVARADO, M. A., WALISZEWSKI, K. N. and KUBIAK. 1994. Modeling of water activity and enthalpy of water sorption in cassava chips Drying Technol., 12, 1743-1752.

SOKHANSANJ, S. and JAYAS, D. S. 2014. Drying of foodstuffs. In Handbook of Industrial Drying, (A. S. Mujumdar, ed.) pp. 521-544, $4^{\text {th }}$ Ed., CRC Press, Boca Raton, FL.

SPENCER, D. 2005. Cassava in africa: past, present and future. In A review of cassava in Africa with country case studies on Nigeria, Ghana, the United Republic of Tanzania, Uganda and Benin, pp. 62-74, FAO, Rome.

SRIROTH, K., PIYACHOMKWAN, K., WANLAPATIT, S. and OATES, C. G. 2000. Cassava Starch Technology: The Thai Experience. Starch - Stärke, 52, 439-449.

STEVENS, D. J. and ELTON, G. A. H. 1971. Thermal properties of the starch/water system Part I. Measurement of heat of gelatinisation by differential scanning calorimetry. Starch - Stärke, 23, 8-11.

STRUMIŁŁO, C., JONES, P. L. and ŻYŁŁA, R. 2014. Energy aspects in drying. In Handbook of Industrial Drying, (A. S. Mujumdar, ed.) pp. 1077-1100, $4^{\text {th }}$ Ed., CRC Press, Boca Raton, FL.

TIVANA, L. D., DEJMEK, P. and BERGENSTÅHL, B. 2010. Characterization of the agglomeration of roasted shredded cassava (Manihot esculenta Crantz) roots. Starch - Stärke, 62, 637-646.

WATSON, K. M. 1943. Thermodynamics of the liquid state. Industrial \& Engineering Chemistry, 35, 398-406.

WHEATLEY, C. C., CHUZEL, G. and ZAKHIA, N. 2003. Cassava: Uses as a raw material. In Encyclopedia of Food Sciences and Nutrition, $2^{\text {nd }}$ Edition, (B. Caballero, ed.) pp. 969-974, Academic Press, Oxford, UK.

WMO. 2008. Guide to Meteorological Instruments and Methods of Observation, $7^{\text {th }}$ Ed., World Meteorological Organization (WMO), Geneva, Switzerland. 


\section{FIGURE CAPTION}

FIG. 1. MEASUREMENT LOCATIONS FOR (a) THE TUNNEL DRYER, AND (b) THE PNEUMATIC DRYER ( $T$, TEMPERATURE; $\varphi$, RELATIVE HUMIDITY; $P$, PRESSURE; $E$, ELECTRIC ENERGY; $v$, AIR VELOCITY; $X$, MOISTURE CONTENT; $\dot{m}$, MASS FLOW RATE) 
FIG. 1. MEASUREMENTS LOCATIONS FOR (a) THE TUNNEL DRYER, AND (b) THE PNEUMATIC DRYER ( $T$, TEMPERATURE; $\varphi$, RELATIVE HUMIDITY;

$P$, PRESSURE; $E$, ELECTRIC ENERGY; $v$, AIR VELOCITY; $X$, MOISTURE CONTENT; $\dot{m}$, MASS FLOW RATE)

(a)

$T$

$\varphi_{\text {out }}$
$T_{\mathrm{amb}}$

$\varphi_{\mathrm{amb}}$

$P$

amb

$\mathcal{V}_{\mathrm{amb}}$

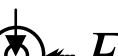

(b)

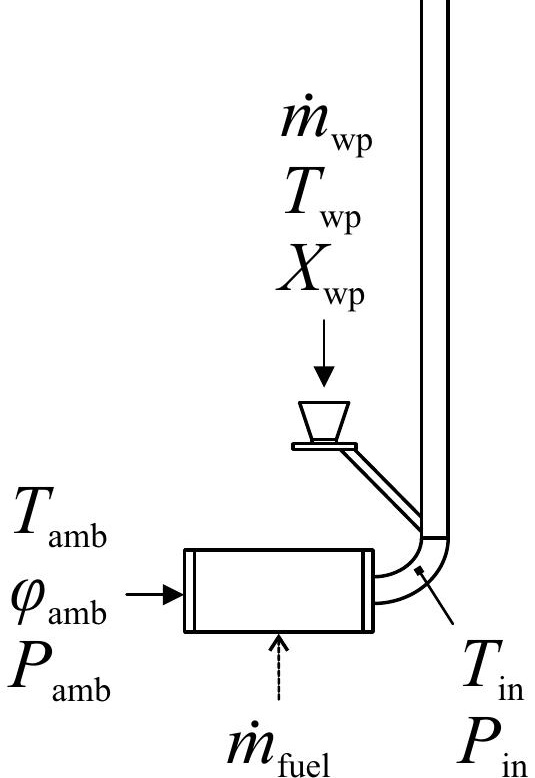

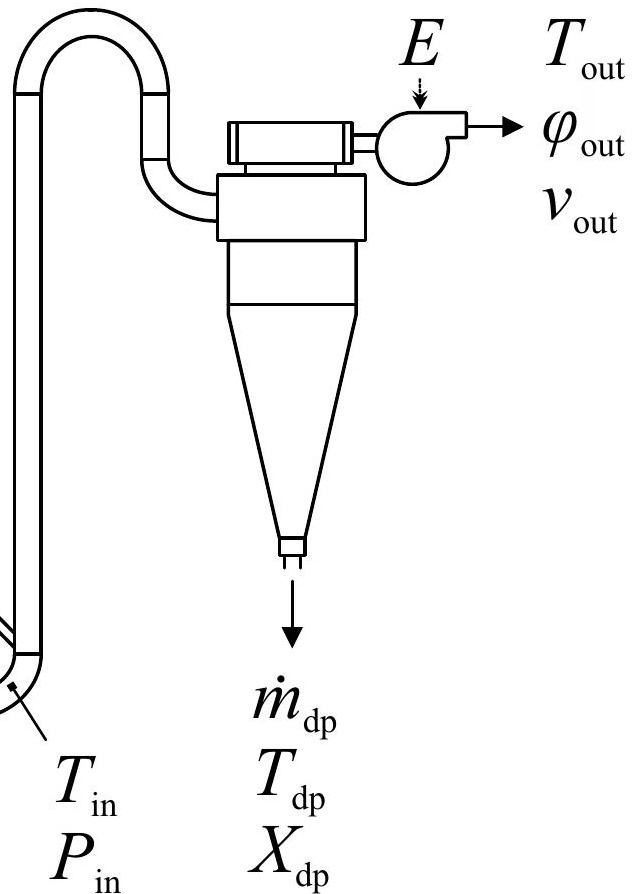


TABLE 1. MEANS AND STANDARD DEVIATIONS (SD) OF THE PERFORMANCE INDICES FOR THE TUNNEL DRYER ACROSS ALL FIVE TRIALS

\begin{tabular}{lccc}
\hline Performance indices & Unit & Mean \pm SD \\
\hline Heat rate added to the ambient air $\left(\dot{Q}_{\Delta}\right)$ & $\mathrm{kW}$ & $12.2 \pm 1.8$ \\
Specific energy consumption $\left(q_{\mathrm{s}}\right)$ & $\mathrm{MJ} / \mathrm{kg}_{\text {water }}$ & $8.5 \pm 1.0$ \\
Energy efficiency $\left(\eta_{\mathrm{e}}\right)$ & $\%$ & $28.7 \pm 3.2$ \\
Thermal efficiency $(\eta \mathrm{T})$ & $\%$ & $57.0 \pm 2.5$ \\
Heat losses to the ambient $\left(\dot{Q}_{\mathrm{L}, \mathrm{amb}}\right)$ & $\%$ & $11.5 \pm 1.8$ \\
Heat loss via exhaust air $\left(\dot{Q}_{\mathrm{L}, \text { out }}\right)$ & $\%$ & $50.5 \pm 3.0$ \\
\hline
\end{tabular}


TABLE 2. MEANS AND STANDARD DEVIATIONS (SD) OF THE PERFORMANCE INDICES FOR THE PNEUMATIC DRYER ACROSS ALL FIVE TRIALS

\begin{tabular}{|c|c|c|c|c|}
\hline Performance indices & Unit & Mean & \pm & SD \\
\hline Heat rate added to the ambient air $\left(\dot{Q}_{\Delta}\right)$ & kW & 173.0 & \pm & 11.4 \\
\hline Specific energy consumption $\left(q_{\mathrm{s}}\right)$ & $\mathrm{MJ} / \mathrm{kg}_{\text {water }}$ & 5.4 & \pm & 0.8 \\
\hline Energy efficiency $\left(\eta_{\mathrm{e}}\right)$ & $\%$ & 45.8 & \pm & 5.8 \\
\hline Thermal efficiency $(\eta \mathrm{T})$ & $\%$ & 87.9 & \pm & 1.1 \\
\hline Heat losses to the ambient $\left(\dot{Q}_{\mathrm{L}, \mathrm{amb}}\right)$ & $\%$ & 30.9 & \pm & 5.9 \\
\hline Heat loss via exhaust air ( $\left.\dot{Q}_{\mathrm{L}, \mathrm{out}}\right)$ & $\%$ & 7.2 & \pm & 7.3 \\
\hline
\end{tabular}

